\title{
From skeletal to non skeletal: The intriguing roles of BMP-9: A literature review
}

\author{
E. Leblanc ${ }^{1,2,3}$, G. Drouin ${ }^{3,4}$, G. Grenier ${ }^{3,4}$, N. Faucheux ${ }^{5}$, R. Hamdy ${ }^{1,2}$ \\ ${ }^{1}$ Department of Surgery, Orthopedic Surgery Division, McGill University, Montreal, Canada \\ ${ }^{2}$ Shriners Hospital for Children, Montreal, Canada \\ ${ }^{3}$ Department of Surgery, Orthopedic Surgery Division, Université de Sherbrooke, Sherbrooke, Canada \\ ${ }^{4}$ Étienne-Lebel Clinical Research Centre, Université de Sherbrooke, Sherbrooke, Canada \\ ${ }^{5}$ Department of Chemical and Biotechnological Engineering, Université de Sherbrooke, Sherbrooke, Canada \\ Email: elisabeth.leblanc2@usherbrooke.ca
}

Received 13 August 2013; revised 14 September 2013; accepted 1 October 2013

Copyright (C) 2013 E. Leblanc et al. This is an open access article distributed under the Creative Commons Attribution License, which permits unrestricted use, distribution, and reproduction in any medium, provided the original work is properly cited.

\begin{abstract}
In the well-known superfamily of transforming growth factors beta (TGF- $\beta$ ), bone morphogenetic proteins (BMPs) are one of the most compelling cytokines for their major role in regulation of cell growth and differentiation in both embryonic and adult tissues. This subfamily was first described for its ability of potentiating bone formation, but nowadays, the power of BMPs is well beyond the bone healing scope. Some of the BMPs have been well studied and described in the literature, but the BMP9 is still worthy of attention. It has been shown by many authors that it is the most potent osteogenic BMP. Moreover, it has been described as one of the rare circulating BMPs. In this paper, we will review the recent literature on BMP9 and the different avenues for future research in that field. Our primary scope is to review its relation to bone formation and to elaborate on the available literature on other systems.
\end{abstract}

Keywords: BMP9; Review; Osteogenesis;

Chondrogenesis; Angiogenesis; Tumorigenesis;

Neurogenesis; Glucose Metabolism

\section{INTRODUCTION}

Fifty years ago, Urist et al. first reported that demineralized bone matrix could promote ectopic bone formation by stimulating transformation of primitive mesenchymal cells of soft tissues into osteogenic cells [1]. Among the growth factors with osteoinductive potential within the bone matrix, the most important seem to be the bone morphogenetic proteins (BMPs). BMPs belong to the transforming growth factor beta (TGF- $\beta$ ) superfamily.
This group of proteins is characterized by a polybasic proteolytic processing site which is cleaved to produce a mature protein containing seven conserved cysteine residues [2]. More than 20 BMPs have been identified to date [3], and most of them homodimerize via disulphide bridges to be active, although heterodimers have been described and are proposed to be more powerful [4,5].

Classically, BMPs are subdivided in four classes based on their sequence homology: BMP 2/4, BMP 5/6/7/8, BMP 9/10 and BMP 12/13/14 [6,7]. The sequence similarity of the members of these subclasses is more than $50 \%$ and is also quite conserved across species $[8,9]$. BMPs signal through serine/threonine kinase receptors composed of type I and II subtypes that activate the Smad pathway and some mitogen activated protein kinases (MAPKs) (Miyazono, 2005 \#94; Bandyopadhyay, 2013 \#320). Genetic disruption of BMP pathways can result in skeletal and extraskeletal abnormalities by their major role in cell proliferation and differentiation during development $[10,11]$.

BMPs can also be classified by their osteogenic potential. To date, BMP2/4/6/7/9 have been identified as having osteogenic properties, notably for their involvement in the regulation of osteoblast differentiation [12-16] and bone formation [14,17]. From this BMP group, BMP9 has been shown to be the most osteogenic [14]. This might be due to the lack of inhibition of BMP9 by noggin, an extracellular antagonist of BMP-2 or BMP-7 [12,18]. While some BMPs such as BMP 2/3/4/6/7/8 can be produced by preosteoblasts [19], BMP9 is mainly produced in the liver [20,21]. BMP9 is also circulating at active concentrations and is known to be a vascular quiescence factor [22]. BMP9 is the physiological ligand of the endothelial receptor ALK1 (activin receptor-like kinase 1, also known as Acvrl1) in association with BMPRII [23- 
25]. ALK1 is one of the seven type I recaptors for TGF- $\beta$ family members [26].

Review articles on BMP9 are needed to better understand its potential. Lamplot $e t$ al. have recently reviewed BMP9 signaling in depth. In this study, the osteogenic pathways including the Smad and different mediators of BMP9 were reviewed. They also point out crosstalk with other factors such as TGF- $\beta 1$, Wnt $/ \beta$-catenin signaling, Growth hormone, Mitogen activated protein kinases (MAPKs), Hypoxia inducible factor 1 alpha (HIF1 $\alpha$ ), Notch, Peroxisome proliferator-activated receptor gamma (PPAR- $\gamma$ ), insulin-like growth factor (IGF) and retinoid acid [27]. Here, we propose an overview of the multiple roles of BMP9 in cell proliferation and differentiation and its relation to current clinical issues. The compelling osteogenic potential of BMP9 will be discussed, but also its role bone resorption, chondrogenesis, cancer development, angiogenesis, neurogenesis, hepatocyte physiology, glucose metabolism, and myogenesis (Figure 1).

\section{MECHANISM OF ACTION}

BMPs transduce signal through serine/threonine kinase heterotetramer receptors composed of two type I and two type II receptors. Once the BMP binds to the receptor complex, the type II receptors phosphorylate the type I receptors. Signal will then transduce via Smad (canonical) or non-Smad pathways. In the canonical Smad pathway, type I receptors phosphorylate the receptor regulatedSmads (R-Smad), i.e. Smad1/5/8 which then recruit the common mediator-Smad4 (coSmad). The R-Smad/coSmad complex translocates to the nucleus and regulates target gene transcription by binding to Smad elements in their promoters $[6,28]$. The Smad-independent pathway $[28,29]$.

In mice and humans, seven TGF- $\beta$ family type I receptors (activin receptor-like kinase; ALK1 to ALK7) have been identified. Luo et al. have demonstrated by dominant negative mutations and RNAi studies that only ALK1 and ALK2 mutants inhibited BMP9-induced Smad activity in bone marrow mesenchymal stem cells as well as osteogenic differentiation and ectopic bone formation [30]. Brown et al. found that BMP9 has a strong relative affinity for ALK1 and for BMPRII, one of the five different TGF- $\beta$ family type II receptors that have been identified (ActRIIA, ActRIIB, BMPRII,

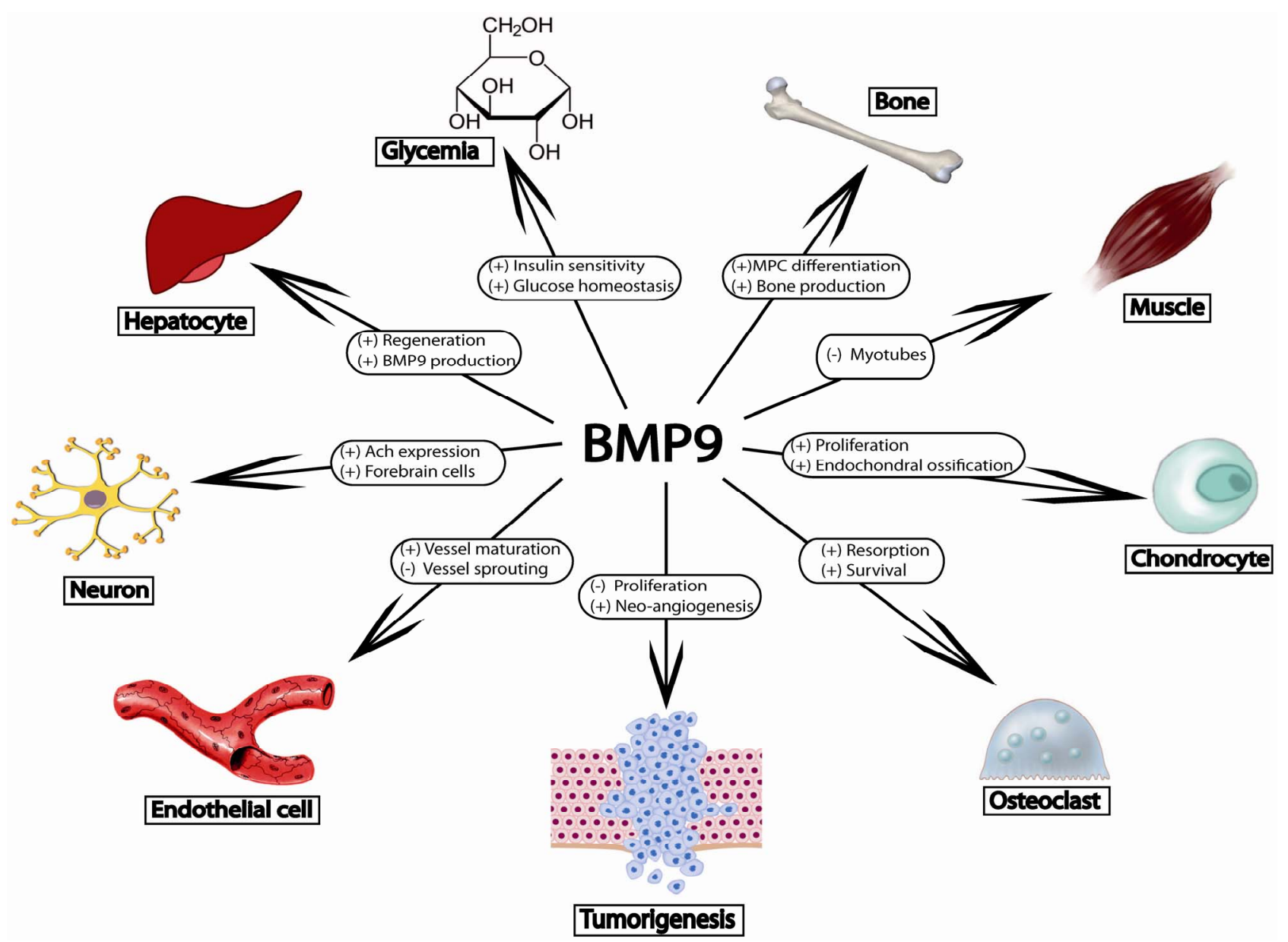

Figure 1. The multiple effects of BMP9. (-): downregulation; (+): upregulation, MPC: mesenchymal progenitor cells. 
TGFBRII and AMHRII) [23]. BMP9 also has a good affinity for Activin RIIA, another type II receptor [23]. More recently, Townson et al. analyzed the kinetic and thermodynamic properties of BMP9 with the different type II receptors and they noticed that ActRIIB had the strongest affinity for BMP9 followed by BMPRII. The affinity of BMP9 for ActRIIA was 300-fold weaker than for ActRIIB [31].

To date, amongst all BMPs, only BMP2/4/6/7 and 9 have been identified to have osteogenic properties and BMP9 seems to be the one with the strongest osteogenic potential [14\{Li, $2003 \# 7]\}$. Few studies tried to understand why BMP9 has this strong osteogenic potential. First, Bergeron et al. have shown that the Smad phosphorylation induced by BMP9 was not prevented by noggin, an extracellular antagonist of the BMP pathway [12]. These data were recently confirmed by two studies by Wang et al. and Luther et al. and reinforced the hypothesis that the high osteogenic capacity of BMP9 is probably augmented by its noggin resistance [18,32]. Kang et al. also showed that BMP3 inhibited the osteogenic potential of BMP2 and BMP7 but had no effect on BMP9 [14]. To date, no BMP9 inhibitor has been identified. Moreover, BMP9 is a secreted protein that has a pro-region but this pro-region does not seem to functionally inhibit BMP9; quite opposite, the pro-region may stabilize and protect BMP9 in vivo [23]. Finally, BMP9 has synergistic partners that would enhance its effects. Growth hormones have been shown to be upregulated by BMP9 and act synergistically to promote endochondral ossification in mesenchymal progenitor cells (MPC) [33]. EGF also demonstrated an increase in BMP9-induced bone formation in cultured mouse fœtal limb explants. In MPCs, BMP9 expression was up-regulated when EGF was present. Furthermore, EGF receptor expression was directly up-regulated by BMP9 [34]. These specific features could, in part, explain the strong osteogenic potential of BMP9 as compared to other osteogenic BMPs.

Production of endogenous BMP9 is mainly located in the liver [20,21]. Indeed, BMP9 transcripts were lower in the human lung (400 fold less), brain (470 fold less) and bone marrow (3400 fold less) than in the liver [21]. Using Harlan Sprague Dawley rats, Miller et al. have first identified the non-parenchymal liver cells (Kupffer and endothelial cells) as BMP9 producers, no BMP9 being detectable in hepatocytes [20]. In contrast, Bidart et al. (2012) have recently found, using human liver biopsies, that BMP9 is present in hepatocytes and intrahepatic biliary epithelial cells [21]. In their experimental conditions, BMP9 was not detected in blood vessel walls and mesenchyme [21]. BMP9 mRNA was also detected by semi quantitative reverse transcription polymerase chain reaction (RT-PCR) in both fresh human endochondral (iliac bone) and intramembranous (mandible) bones [35].
Primary cultures of osteoblastic cells extracted from human intramembranous and endochondral bones seem to be able to synthesize BMP9 [35]. BMP9 is also found in human circulation (2 - $12 \mathrm{ng} / \mathrm{mL}$ ) under two forms: an active (60\%) and inactive form (40\%) that can be further activated by a serine endoprotease to a mature and fully active form [21]. A mouse development study revealed that BMP9 circulating levels peak within 3 weeks after birth (with a peak at about $6 \mathrm{ng} / \mathrm{mL}$ ) and decrease to 2 $\mathrm{ng} / \mathrm{mL}$ in adulthood [21].

\section{BMP9 AND BONE FORMATION}

The first report about BMP9 as an osteogenic factor is in the mid 90's by Celeste et al. [36]. In this study, the authors describe the molecular cloning and biological activity of this new member of the TGF- $\beta$ superfamily [36]. The osteogenic potential of BMP9 was then mostly tested through viral vectors to promote bone formation in many clinical settings.

Hence, Alden et al. [37] showed that they could fill a cranio-facial critical bone defect in rats with an adenoviral human BMP9 vector. Radiologic and histologic analyses of the mandibular bones demonstrated significant bony healing compared to adenoviral $\beta$-galactosidase controls. Also, the mechanism through which bone was formed during the critical defect healing was proven to be endochondral ossification [37].

In the spinal region, BMPs have been shown to promote spinal arthrodesis at a higher rate than autologous bone alone, and to BMP2 and 7, which are actually approved for this specific indication [38]. Another group has evaluated the efficacy of the use of a direct percutaneous injection of BMP9 expressing adenovirus to promote spinal fusion in rats [39]. The animals were directly injected with viral vectors in the lumbar paraspinal musculature and were sacrificed after 16 weeks. Computerized tomography studies and histological analysis demonstrated bone induction at the injection sites, leading to solid spinal arthrodesis. The authors did not have any evidence of pseudarthroses, nerve root compression, or systemic side effects. This study, while strongly supporting the advancement of BMP gene therapy techniques toward clinical use, has also shown that the use of BMP9 through gene therapy could be an interesting avenue to explore [39].

In a similar experimental design, ex vivo BMP9 gene therapy on human mesenchymal stem cells (hMSCs) has been proven to be efficacious for spinal fusion in rats. Indeed, Dumont et al. infected ex vivo hMSCs by using adenovirus (Ad) containing BMP9's chimeric sequence composed of the murine BMP9 proregion and human mature region under the control of cytomegalovirus (CMV) promoter [40]. The infected hMSCs by AdBMP9 or $\mathrm{Ad} \beta$-galactosidase used as control were then injected 
in paraspinal muscles of nude athymic rats. After only 8 weeks, rats treated with BMP9 expressing cells, showed radiographically and histologically massive ectopic bone formation leading to spinal fusion [40]. The results of this study suggested that gene therapy on hMSCs ex vivo using CMV driven BMP9 expression was possible and may be useful to induce spinal fusion. While showing the effect of BMP9 on hMSCs, this study also brought a more attractive way of using BMP gene therapy. The year after, the same team showed that a similar injection of AdBMP9 ex vivo treated hMSCs was able to produce ectopic bone formation in the hindlimbs musculature of athymic nude rats [41].

Heterotopic bone formation by itself can turn out to be useful if the muscle is used as a vascularised bone graft. Hence, the latissimus dorsi muscle from nude rat was infected with an adenoviral vector of BMP9 to make a vascularised bone flap using heterotopic ossification as an advantage [42]. With weekly biopsies and using RTPCR and immunohistochemistry, they found that the muscle expressed chondrogenic and then osteogenic markers through the 3 weeks following the injection. They estimated that the flap harvest should be after 2 weeks to be used as a vascularised moldable bone graft [42].

Gene therapy has been shown to be efficient, but the transfer in humans is problematic because of its viral nature and the existing lack of control over that kind of technology. To work around that scientific and ethical issue, nucleofecting hMSCs with nonviral plasmid expressing hBMP9 was developed [43]. Nonviral gene transfer is safer, can be controlled and is reproducible. hBMP9-nucleofected hMSCs in culture demonstrated an increase in calcium deposition compared to control EGFP (enhanced green fluorescent protein) nucleofected hMSCs. Moreover, hBMP9-nucleofected hMSCs transplanted in ectopic sites in mice induced bone formation 28 days post-injection [43]. This safe and attractive alternative was a breakthrough in the field of regenerative medicine at the time, however this technique is demanding.

In the late 70's, Boyer's team synthetized the first functional polypeptide product from a gene of chemically synthesized origin [44]. This turning point in biotechnology opened the door to the use of recombinant proteins for clinical purpose. The use of recombinant proteins is safer than viral gene transfer and yet more accessible than nucleofection. Furthermore, the availability of recombinant BMP9 has liberalized its use and led to more accessible research on its osteogenic potential. Even if recombinant human BMP9 (rhBMP9) was used by Song and Celeste in the mid 90's, reports on its use for bone formation assays appear 10 years later in the mid 2000's $[12,36,45,46]$. The interest of using rhBMP9 is also related to the controlled dosage and an easier correlation to its effect. Thus rhBMP9 produced by E. coli at $500 \mathrm{ng} / \mathrm{mL}$ was shown to induce after 5 days the expression of early markers of bone differentiation such as smad- $1 / 5$, run $\times 2$, dl $\times 5$, osterix, osteopontin, bone sialoprotein and alkaline phosphatase in C2C12 cells [47]. In the same manner, Bergeron et al. have shown that a peptide derived from BMP9, pBMP9 is able to induce osteoblastic differentiation in pre-osteoblasts $[12,48]$.

The osteoinductive potential of rhBMP9 was especially determined in the context of muscular heterotopic ossification (HO). Indeed, $\mathrm{HO}$ is a common model to study the mechanism of ossification process in animals [49,50]. On the other hand, this model can be useful in order to obtain a better understanding of the ossification processes occuring in muscle and to treat that condition [50]. Some papers have shown that adult muscle regeneration could be impaired by BMPs [51,52]. Myogenesis was reported to be inhibited by BMPs by their down-regulation on satellite cells fusion [53]. Besides, mesenchymal progenitor cells contained into the muscle are also responsive to BMPs [54,55]. Overall, it was shown that both myogenic and mesenchymal cell populations could be altered by BMP and that tends to go from myogenesis to osteogenesis [16].

Since the most common traumatic form of HO occurs generally at sites of damaged muscles, we hypothesized a relation between damaged muscle microenvironment and BMP9 induced HO [56]. In this paper, we show for the first times that BMP9 induces HO only in damaged muscle. This paper highlighted the importance of cell microenvironment for HO. We also showed that muscle resident stromal cells (mrSCs) are sensitive to BMP9 signaling and express bone specific markers when exposed to BMP9. Interestingly, mrSCs isolated from damaged muscle are more responsive to BMP9. During a transplantation experiment using labeled cells, we demonstrated that mrSCs contribute to HO. Importantly, the addition of a fusion protein containing the receptor ALK1 significantly inhibited the osteoinductive potential of BMP9 in mrSCs in vitro as well as $\mathrm{HO}$ in damaged muscles [56].

Our experimental results show that a better understanding of the ossification processes and BMP implication is essential for developing new bone healing and $\mathrm{HO}$ treatments. They also revealed that the osteoinductive potential of rhBMP9 is highly dependent on the microenvironment [56]. Therefore, delivery systems have to be developed to protect the protein against breakdown. The type of carrier, its concentration as well as the BMP dose used in these delivery systems greatly influence the growth factor release over time and its osteoinductive potential [57]. In vitro and in vivo studies using different delivery systems have been therefore studied throughout 
the years for rhBMP9 and/or its less expensive derived peptide (pBMP9) [48,58,59].

Delivery systems slow-down degradation and enhance the effect of growth factors like BMP9. Bessa et al. has recently developed BMP loaded silk fibroin microparticles as delivery systems of BMP2, 9, or 14 [59]. The encapsulation efficiency of the BMPs loaded at 0.5 or 5 $\mu \mathrm{g}$ varied from $68 \%$ to $98 \%$ and BMP14 was better retained over time than BMP4 and BMP9 in this silk fibroin carrier [59].

The combination of collagen Type I gel, BMP (100 $\mathrm{ng} / \mathrm{mL}$ ) and bioactive glass microspheres (45S5 Bioglass $^{\circledR}, \mathrm{GM}$ ) has been shown to increase osteoblastic differentiation by Bergeron et al. [48]. For this assay, a peptide derived from BMP9 (pBMP9) to treat MC3T3-E1 preosteoblasts was used. Alkaline phosphatase staining showed that pBMP9 induced osteoblast differentiation and that bioactive GM increased this effect. Since preosteoblasts secrete matrix metalloproteinases (MMPs), the influence of the delivery system on MMPs expression was then studied. pBMP9 with bioactive GM generated less MMP than did rhBMP-2 [48]. Thus, this delivery system using a combination of bioactive GM and BMP9 derived peptide seems to be promising.

In vivo experiments also highlighted the importance of the carrier choice. For example, rhBMP9 (169.2 ng/ml) embedded in chitosan can induce endochondral ossification 24 days after injection in quadriceps of mice, while BMP9 entrapped into collagen seems less efficient [58]. pBMP9, a peptide derived from the knuckle epitope of BMP9, is also able to induce bone formation in quadricceps when injected embedded in chitosan [58]. This underlines the importance to optimize carrier and the influence of microenvironment, to improve BMP9 in vivo bone induction. Together, these delivery systems can offer promising approaches for the sustained delivery of BMPs, such as BMP9 for tissue engineering applications and for improving bone formation.

Another alternative to improve bone formation is to develop biomimetic materials that favor cell adhesion and promote their response to rhBMP9 or pBMP9. For example, the functionalization of material by adhesive peptides that target specific integrins can strongly influence the bone cell response to BMP9 and pBMP9 [60, 61]. The peptide derived from the bone sialoprotein AcCGGNGERPRGDTYRAY-NH2 that is recognized by the avb3 integrins promote the early differentiation of MC3T3-E1 preosteoblasts induced by pBMP9. In contrast, pBMP9 had no effect on cells attached through the a2b1 integrins to the peptides Ac-CGGDGEA-NH2 derived from type I collagen [61]. The selection of adhesive peptides to develop biomimetic materials promoting bone cell response to BMPs is therefore critical.

\section{BMP9 AND CHONDROGENESIS}

Chondrogenesis is a multistep process that leads to the formation of cartilage [62]. Understanding chondrogenesis is essential when addressing bone formation since cartilage is part of bone development and repair [62]. The first step of chondrogenesis is the aggregation and condensation of mensenchymal progenitor cells (MPCs) to form chondroprogenitors $[63,64]$. Then, chondroprogenitors differentiate into chondrocytes that proliferate and produce matrix containing collagen II, IX, XI and aggrecan $[63,65]$. The newly formed cartilage serves as a template for the formation of long bone, a process called endochondral ossification [63,66]. Indeed, chondrocytes undergo a terminal differentiation to hypertrophic phenotype, followed by calcification of the cartilage matrix, which leads to its vascularisation and its ossification [63]. Both intramembranous and endochondral bone formation are associated to BMPs, but BMP9 was proposed to be more related to endochondral bone formation [37]. Its proposed implication in endochondral ossification, is highlighting its major role in skeleton development, maintenance and repair [35].

BMP signaling is essential during chondrogenesis; it is required for the condensation of MPCs and their differentiation into chondrocytes [64-66]. Kramer et al. have shown that BMP2 (2 ng/ml; $10 \mathrm{ng} / \mathrm{ml})$ and BMP-4 (10 $\mathrm{ng} / \mathrm{ml}$ ) are able to induce chondrogenic differentiation of embryonic stem cells via embryonic bodies [67]. More interestingly, an increased mRNA expression of BMP1/2/ $5 / 6$ have been reported in human chondrocytes throughout chondrogenic differentiation [68,69] and that adult articular chondrocytes was able to express BMP7 [70]. BMP9 has been shown to induce ectopic bone formation into skeletal muscle [56,71]. This occurs via an endochondral bone process as shown by Varady et al. [71]. They noticed that six days after an intramuscular injection of AdBMP9 vector, MPCs had begun a differentiation into primitive chondroblasts that secreted loose extracellular matrix [71]. Thirteen days post-injection, they also observed hypertrophied chondrocytes. Three weeks post-injection, woven bone appeared and turned into lamellar bone within three months [71]. Majumdar et al. showed that Sox9, a nuclear transcription factor required to undergo chondrogenesis, was upregulated in BMP9 treated MPCs [72]. Furthermore, BMP9 treatment (100 $\mathrm{ng} / \mathrm{ml}$ ) also induced overexpression of Col2a1 and aggrecan after 2 weeks, two important components of the cartilage matrix [72]. Finally, Blunk et al. have shown that BMP9 was able to stimulate the proliferation of primary bovine chondrocytes and extracellular matrix deposition at a concentration of more than $1 \mathrm{ng} / \mathrm{ml}$ and to induce chondrocytes hypertrophy and mineralization when the concentration was above $10 \mathrm{ng} / \mathrm{ml}$ [73]. All these results strongly suggest that BMP9 is a modulator 
of chondrocytes activity.

\section{BMP9 AND BONE RESORPTION}

BMP9, as described above, is involved in chondrogenesis and can strongly promote bone formation. In addition, Fong et al. recently demonstrated in vitro that rhBMP9 can also augment bone resorption [74]. This increase was shown to be functional and not related to osteoclast formation. Furthermore, rhBMP9 could alter the intrinsic apoptosis pathway and increase survival of osteoclasts. The effect of rhBMP9 on osteoclast was explained by the presence of ALK1 and BMPRII co-receptors and their activation of the Smad 1/5/8 and non-smad MAPK/ERK pathways. These results show for the first time that BMP9 can directly affect human osteoclasts, acting on their function and their survival [74].

\section{BMP9 AND CANCER DEVELOPMENT}

There are still discrepancies in studies concerning BMP9 and cancer development. Although some studies suggest that BMP9 promoted differentiation and decreased proliferation, whereas some others have shown the opposite. Indeed, different studies have found that BMP9 restricts tumor growth including prostate cancer, osteosarcoma and colon adenocarcinoma [75-77]. The relation between cancer and BMP9 seems to be mostly through two separate mechanisms: cancer cell migration and invasion as well as angiogenesis process [75-79].

Recent studies analyzed the effect of BMP9 (rhBMP9 or AdBMP9) in different human osteosarcoma cell lines such as MG-63 cells [80,81]. For example, BMP9 expression was obtained through infection of human osteosarcoma MG-63 and 143B cells by a BMP9 expressing adenovirus [82]. Migration and invasion in vitro potential were significantly lower (about 50\% - 55\%) in the infected cells [82]. In a sub-cutaneous nude mice model, the BMP9 overexpressing tumors were found to be significantly smaller [77]. Then, BMP9 was found to induce apoptosis in osteosarcoma cells [77]. Moreover matrix metalloproteinases (MMP), specifically MMP-9, were shown to be decreased significantly by the overexpression of BMP9 in osteosarcoma cells [82]. The loss of migration and invasion potential was suggested to be through a Smad-dependent pathway by downregulating the expression and activity of MMP9 [77,82].

Furthermore, BMPs have been implicated in the production of bone metastases in prostate cancer [83]. However, based on the observation that the expression of BMP9 was decreased or absent in higher grade prostate cancer, Ye et al. investigated the influence of BMP9 on the biology of prostate cancer cells [76]. They showed that the overexpression of BMP9 reduced cell growth, matrix adhesion, invasion, and migration of prostate can- cer PC-3 cells. They also showed that BMP9 induced apoptosis in those particular cells through the overexpression of the prostate apoptosis response-4. The effect of BMP9 on PC-3 cells relied on Smad-dependent signal transduction. Thus, knockdown of BMPR-IB or BMPRII could promote PC-3 growth in vitro, but it had no significant effect on their invasion potential. This suggests that BMP9 may function as a tumor suppressor and apoptosis regulator in prostate cancer through diverse mechanisms [76].

Regarding angiogenesis, BMP9 has been shown to be linked to vascular maturation [22]. However, contradictory studies about the role of TGF- $\beta$ and other family members with reported vascular functions, such as BMP9, in physiological and pathological angiogenesis make the need for more comprehensive studies.

\section{BMP9 AND ANGIOGENESIS}

The effect of BMP9 on angiogenesis remains controversial as both pro [79] and anti-angiogenic [22] effects have been demonstrated. This discrepancy can be explained by different dosages, but also microenvironment and the subtle interplay between vascular sprouting and maturation [84]. The interest of studying BMP9 in angiogenesis resides in two principal pathologic angiogenesis conditions: cancer angiogenesis and vascular diseases per se (Hereditary Hemorrhagic Telangiectasia (HHT), pre-eclampsia, pulmonary arterial hypertension (PAH)).

BMP9 has been reported to bind to ALK1 in endothelial cells [24]. It was also shown using rat aortic cross sections that circulating BMP9 induces a constitutive Smad1/5/8 phosphorylation in endothelial cells [21]. However, the roles of BMP9-ALK1 signaling in the regulation of endothelial cells have not yet been fully elucidated. Suzuki et al. examined the effects of BMP9 on the proliferation of endothelial cells. Vascular tube formation from ex vivo mouse embryonic allantois explants and proliferation of in vitro cultured mouse stem cell-derived endothelial cells (MESECs) was both promoted by BMP9 [79]. This effect was shown to be related to ALK1 signaling, supported by the mimicked proangiogenic effect of the expression of constitutively active ALK1 in MESECs. Furthermore, in vivo angiogenesis was promoted by BMP9 in a Matrigel plug assay and in a mouse xenograft model after subcutaneous injection of BxPC3 human pancreatic adenocarcinoma cells infected with lentiviruses encoding BMP9. Taken together, these results showed that BMP9 enhanced the proliferation of normal endothelial cells and tumor-associated endothelial cells [79].

Through genetic and pharmacological means, Cunha demonstrated that ALK1 represents a new therapeutic target for tumor angiogenesis [78]. Using a soluble fu- 
sion protein of ALK1 with an immunoglobulin (ALK1$\mathrm{Fc}$ ), they have been able to inhibit the BMP9-ALK1 signaling. Systemic treatment with the ALK1-Fc fusion protein RAP-041 (12 mg/kg), which acts as a competitive inhibitor of BMP9, delayed pancreatic tumor growth and progression, as diminution of ALK1 gene dosage also did. This delayed growth was thought to be related to the inhibition of angiogenesis. Furthermore, the use of RAP041 significantly impaired angiogenic response toward vascular endothelial growth factor A (VEGFA). In that study, they found that the observed effect was related to an unexpected synergy between TGF- $\beta$ and BMP9. In fact, the combined action of the two factors augmented the response to angiogenic stimuli of the endothelial cells [78]. This finding reinforces the idea that BMP9 can have a dual effect on angiogenesis and that its pro-angiogenic effect may be dependent on TGF- $\beta$ synergy. The same year, another team showed a diminution of vessel formation in a chick chorioallantoic assay and a reduced tumor burden in both melanoma explants and mammary adenocarcinomas with ALK1-Fc treatment [85].

Later, Cunha et al. presented another paper on the critical role for ALK1, reviewing its effect on the endothelial phenotype in vitro and in vivo [25]. These findings have led to the development of new ALK1 pathway inhibitors that target different malignant diseases. In the same vein, another group used soluble endoglin ECD as an inhibitor in the regulation of angiogenesis and highlighted the efficacy of this fusion protein as a potential anti-angiogenic drug [75]. They showed that this inhibitor reduced the VEGF-induced angiogenesis and the tumor burden in a mouse colon cancer model.

Angiogenesis requires a finely tuned balance between numerous signals and although BMP9 has been shown to have pro-angiogenic potential (above), other studies have shown the opposite. Indeed, a team has been working a lot on the relationship between endothelial cells and ALK1 [21,24,86]. Using NIH3T3 fibroblasts, found that BMP9 signal transduction involved ALK1 and both BMPRII and ActRIIA. Moreover, by overexpressing endoglin in NIH3T3 fibroblasts, they promoted the BMP9 stimulation of ALK1. BMP9 could inhibit endothelial cell migration and growth, and activate the expression of genes encoding proteins related to vascular maturation such as Id1, Id2, Smad6, Smad7, endoglin and BMPRII [24].

A year after, they reviewed the presence of BMP9 in human serum to verify whether in fact it could be implied in vascular quiescence. First, they found that human serum alone could induce Smad1/5 phosphorylation in NIH3T3 transfected by ALK1 expression plasmid. Second, they identified the active factor by using antibodies against all BMP members and found that only the
anti-BMP9 inhibited this Smad1/5 phosphorylation [22]. These results were refined by data from Herrera and Inman (2009) where they identified circulating BMP4 and 9 as active BMPs in human sera with a luciferase reporter fused with the promoter BMP response element Id1, transfected in a C2C12 line [87]. Present at a concentration between 2 and $12 \mathrm{ng} / \mathrm{mL}$ in human plasma, BMP9 is circulating at a biologically active concentration $\left(\mathrm{EC}_{50}=50 \mathrm{pg} / \mathrm{mL}\right)$. BMP9 was then tested in vivo in angiogenic assays. Both in vivo mouse cellulose sponge angiogenesis and chicken chorioallantoic membrane assays showed that BMP9 could negatively affect angiogenesis may play a role in vascular quiescence [22]. Interestingly, the role of BMPs in angiogenesis opened the door to a better understanding of genetic vascular diseases caused by mutations in genes encoding for recaptors of this pathway (endoglin, ALK1 and BMPRII). This leads to an important review in which the authors proposed a model to distinguish BMP2, BMP7 and GDF5 from BMP9 in their functional implication in vessel formation and maturation [84].

Hereditary Hemorrhagic Telangiectasia (HHT), also known as Rendu-Osler-Weber, is a disease that causes frequent nose bleeds, mucocutaneous and visceral telangiectasia [88]. This pathology follows an autosomaldominant inheritance pattern which has been shown to be linked in $80 \%$ to a mutation in ALK1 or the co-receptor endoglin [89]. Endoglin is a transmembrane glycoprotein on human vascular endothelial cells and is a co-receptor implicated in this dominant vascular dysplasia as well as in preeclampsia [90]. The alteration of ALK1 or endoglin affects the maturation phase of angiogenesis, leading to the absence of capillaries connecting the arterial and venous networks [89]. As BMP9 acts as the specific ligand of the receptor ALK1 and to endoglin as its co-receptor, a defect in either members of the receptor complex means a disrupted BMP9 signaling pathway. Heterozygous mice for endoglin or ALK1 supports the involvement of endothelial hyperproliferation in the pathogenesis of the disease while the maturation is disrupted [91]. More recently, Choi et al. demonstrated that ALK1 deficient endothelial cells have high migratory and invasion properties both in vitro and in vivo. This new data confirms the importance of BMP9-ALK1 for angiogenesis and into the differentiation and maturation of neocapillaries [92]. This BMP9-ALK1 signaling in angiogenesis was shown to be transmitted downstream through Tmem 100 , a gene encoding a previously uncharacterized intracellular transmembrane protein [93].

On the other hand, pulmonary arterial hypertension $(\mathrm{PAH})$ is characterized by dysregulation in pulmonary artery endothelial cell proliferation, apoptosis and permeability. The most common cause of inheritable PAH is a mutation in the BMPR-II, leading to a loss of its func- 
tion [94]. In the same way as the defective signaling of ALK1-endoglin in HHT, a deficient BMPRII signaling leads to an absent function of BMP9 and to an anarchic development of blood vessels [94].

Recently, it has been shown that chloroquine, an antimalarial drug, is able to indirectly increase cell surface expression of BMPRII in pulmonary artery endothelial cells [95]. This increase seemed to be independent from transcription since chloroquine enhanced BMPRII expression even after siRNA knockdown of the BMPRII transcript. Using BMPRII deficient cells from PAH sick patients, BMP9 signaling was also shown to be decreased and treatment with chloroquine significantly increased expression of BMP9-BMPRII signaling gene targets. These findings provide new insights for the restoration of cell surface receptors in treating hereditary vascular diseases, specifically BMPR-II with chloroquine for treatment of PAH [95].

The effect of BMP9 on angiogenesis remains controversial as both pro [79] and anti-angiogenic [22] effects have been demonstrated. This discrepancy can be explained by different dosages, but also microenvironment and the subtle interplay between vascular sprouting and maturation [84]. The interest of studying BMP9 in angiogenesis resides in two principal pathologic angiogenesis conditions: cancer angiogenesis and vascular diseases per se (Hereditary Hemorrhagic Telangiectasia (HHT), pre-eclampsia, pulmonary arterial hypertension (PAH)).

BMP9 has been reported to bind to ALK1 in endothelial cells [24]. It was also shown using rat aortic cross sections that circulating BMP9 induces a constitutive Smad1/5/8 phosphorylation in endothelial cells [21]. However, the roles of BMP9-ALK1 signaling in the regulation of endothelial cells have not yet been fully elucidated. Suzuki et al. examined the effects of BMP9 on the proliferation of endothelial cells. Vascular tube formation from ex vivo mouse embryonic allantois explants and proliferation of in vitro cultured mouse stem cell-derived endothelial cells (MESECs) was both promoted by BMP9 [79]. This effect was shown to be related to ALK1 signaling, supported by the mimicked proangiogenic effect of the expression of constitutively active ALK1 in MESECs. Furthermore, in vivo angiogenesis was promoted by BMP9 in a Matrigel plug assay and in a mouse xenograft model after subcutaneous injection of BxPC3 human pancreatic adenocarcinoma cells infected with lentiviruses encoding BMP9. Taken together, these results showed that BMP9 enhanced the proliferation of normal endothelial cells and tumor-associated endothelial cells [79].

Through genetic and pharmacological means, Cunha demonstrated that ALK1 represents a new therapeutic target for tumor angiogenesis [78]. Using a soluble fu- sion protein of ALK1 with an immunoglobulin (ALK1Fc), they have been able to inhibit the BMP9-ALK1 signaling. Systemic treatment with the ALK1-Fc fusion protein RAP-041 (12 mg/kg), which acts as a competitive inhibitor of BMP9, delayed pancreatic tumor growth and progression, as diminution of ALK1 gene dosage also did. This delayed growth was thought to be related to the inhibition of angiogenesis. Furthermore, the use of RAP041 significantly impaired angiogenic response toward vascular endothelial growth factor A (VEGFA). In that study, they found that the observed effect was related to an unexpected synergy between TGF- $\beta$ and BMP9. In fact, the combined action of the two factors augmented the response to angiogenic stimuli of the endothelial cells [78]. This finding reinforces the idea that BMP9 can have a dual effect on angiogenesis and that its pro-angiogenic effect may be dependent on TGF-b synergy. The same year, another team showed a diminution of vessel formation in a chick chorioallantoic assay and a reduced tumor burden in both melanoma explants and mammary adenocarcinomas with ALK1-Fc treatment [85].

Later, Cunha et al. presented another paper on the critical role for ALK1, reviewing its effect on the endothelial phenotype in vitro and in vivo [25]. These findings have led to the development of new ALK1 pathway inhibitors that target different malignant diseases. In the same vein, another group used soluble endoglin ECD as an inhibitor in the regulation of angiogenesis and highlighted the efficacy of this fusion protein as a potential anti-angiogenic drug [75]. They showed that this inhibitor reduced the VEGF-induced angiogenesis and the tumor burden in a mouse colon cancer model.

Angiogenesis requires a finely tuned balance between numerous signals and although BMP9 has been shown to have pro-angiogenic potential (above), other studies have shown the opposite. Indeed, a team has been working a lot on the relationship between endothelial cells and ALK1 $[21,24,86]$. Using NIH3T3 fibroblasts, found that BMP9 signal transduction involved ALK1 and both BMPRII and ActRIIA. Moreover, by overexpressing endoglin in NIH3T3 fibroblasts, they promoted the BMP9 stimulation of ALK1. BMP9 could inhibit endothelial cell migration and growth, and activate the expression of genes encoding proteins related to vascular maturation such as Id1, Id2, Smad6, Smad7, endoglin and BMPRII [24].

A year after, they reviewed the presence of BMP9 in human serum to verify whether in fact it could be implied in vascular quiescence. First, they found that human serum alone could induce Smad1/5 phosphorylation in NIH3T3 transfected by ALK1 expression plasmid. Second, they identified the active factor by using antibodies against all BMP members and found that only the anti- 
BMP9 inhibited this Smad1/5 phosphorylation [22]. These results were refined by data from Herrera and Inman (2009) where they identified circulating BMP4 and 9 as active BMPs in human sera with a luciferase reporter fused with the promoter BMP response element Id1, transfected in a C2C12 line [87]. Present at a concentration between 2 and $12 \mathrm{ng} / \mathrm{mL}$ in human plasma, BMP9 is circulating at a biologically active concentration $(\mathrm{EC} 50=50 \mathrm{pg} / \mathrm{mL})$. BMP9 was then tested in vivo in angiogenic assays. Both in vivo mouse cellulose sponge angiogenesis and chicken chorioallantoic membrane assays showed that BMP9 could negatively affect angiogenesis may play a role in vascular quiescence [22]. Interestingly, the role of BMPs in angiogenesis opened the door to a better understanding of genetic vascular diseases caused by mutations in genes encoding for receptors of this pathway (endoglin, ALK1 and BMPRII). This lead to an important review in which the authors proposed a model to distinguish BMP2, BMP7 and GDF5 from BMP9 in their functional implication in vessel formation and maturation [84].

Hereditary Hemorrhagic Telangiectasia (HHT), also known as Rendu-Osler-Weber, is a disease that causes frequent nose bleeds, mucocutaneous and visceral telangiectasia [88]. This pathology follows an autosomaldominant inheritance pattern which has been shown to be linked in $80 \%$ to a mutation in ALK1 or the co-receptor endoglin [89]. Endoglin is a transmembrane glycoprotein on human vascular endothelial cells and is a co-receptor implicated in this dominant vascular dysplasia as well as in preeclampsia [90]. The alteration of ALK1 or endoglin affects the maturation phase of angiogenesis, leading to the absence of capillaries connecting the arterial and venous networks [89]. As BMP9 acts as the specific ligand of the receptor ALK1 and to endoglin as its co-receptor, a defect in either members of the receptor complex means a disrupted BMP9 signaling pathway. Heterozygous mice for endoglin or ALK1 supports the involvement of endothelial hyperproliferation in the pathogenesis of the disease while the maturation is disrupted [91]. More recently, Choi et al. demonstrated that ALK1 deficient endothelial cells have high migratory and invasion properties both in vitro and in vivo. This new data confirms the importance of BMP9-ALK1 for angiogenesis and into the differentiation and maturation of neocapillaries [92]. This BMP9-ALK1 signaling in angiogenesis was shown to be transmitted downstream through Tmem 100 , a gene encoding a previously uncharacterized intracellular transmembrane protein [93].

On the other hand, pulmonary arterial hypertension (PAH) is characterized by dysregulation in pulmonary artery endothelial cell proliferation, apoptosis and permeability. The most common cause of inheritable PAH is a mutation in the BMPR-II, leading to a loss of its func- tion [94]. In the same way as the defective signaling of ALK1-endoglin in HHT, a deficient BMPRII signaling leads to an absent function of BMP9 and to an anarchic development of blood vessels [94].

Recently, it has been shown that chloroquine, an antimalarial drug, is able to indirectly increase cell surface expression of BMPRII in pulmonary artery endothelial cells [95]. This increase seemed to be independent from transcription since chloroquine enhanced BMPRII expression even after siRNA knockdown of the BMPRII transcript. Using BMPRII deficient cells from PAH sick patients, BMP9 signaling was also shown to be decreased and treatment with chloroquine significantly increased expression of BMP9-BMPRII signaling gene targets. These findings provide new insights for the restoration of cell surface receptors in treating hereditary vascular diseases, specifically BMPR-II with chloroquine for treatment of PAH [95].

Indeed, there still remains controversy on pro and antiangiogenic effects of BMP9. Recent literature highlights the importance of understanding its role in vessel maturation as opposed to formation and also the role of the microenvironment and synergy with TGF-b. On the other hand, it is clear that the signaling pathway is through receptor and co-receptor ALK1-endoglin, and that this can be inhibited by the use of ALK1 or endoglin fusion proteins. Certainly, it will be interesting to test whether some drugs derived from inhibitors like ALK1-Fc could be used experimentally to treat cancer and on the other hand develop ALK1 pathway enhancers that could help to treat hereditary vascular diseases.

\section{BMP9 AND NEUROGENESIS}

BMPs are critical in neurogenesis, forebrain formation and more globally in the dorsoventral axis determination $[96,97]$. BMPs promote cell survival and differentiation of neurons in both peripheral and central nervous systems (CNS) [98] Lopez-Coviella et al. have been working specifically on the cholinergic neurons of the forebrain [99]. Basal forebrain cholinergic neurons (BFCN) participate in processes of learning, memory, attention and their degeneration is involved in several human disorders such as Alzheimer's disease [100]. They have shown that 14 days old mice embryos express BMP9 mRNA principally in the forebrain and spine [99]. This developmental stage is also the one where the cholinergic neurons are most sensitive to BMP9. Thus, cultured primary cells derived from the septal area increase their acetylcholine (Ach) expression by 20 fold when exposed to BMP9 during that period. Compared to 5 other BMPs (BMP2-4-6-7-12), BMP9 is the most potent in inducing Ach expression by septal cells. Moreover, when injected into mouse embryo cerebral ventricles, BMP9 is able to increase cerebral Ach level [99]. The genes responsive to 
this BMP9 induction of basal forebrain neurons include cell-cycle related proteins, transcription factors, signal transduction molecules, extracellular matrix proteins, adhesion molecules, enzymes, transporters, and chaperonins. The set of genes induced with BMP9 treatment suggests that BMP9 creates a trophic environment for basal forebrain neurons and contributes to the maturation of this part of the brain in vivo [101].

During the development of cholinergic neurons of the basal forebrain, BMP9 activates the canonical BMP signaling pathway, through phosphorylation of Smad1 and Smad5 which associate to co-Smad4 and translocate into the nucleus [98]. Finally, this team demonstrated that BMP9 administration can prevent lesion-evoked impairment of the cholinergic hippocampal neurons in adult mice by inducing a favorable environment for these cells [102].

Interestingly, Bissonnette et al. have been able to generate BFCN from human embryonic stem cells (hESCs) using relevant ligands of the developing forebrain [103]. hESCs respond to BMP9 signaling after sonic hedgehog/fibroblast growth factor 8 pretreatment and differentiate the progenitors toward a BFCN phenotype. These derived neurons express only markers characteristic of BFCN and have their functional characteristics (action potentials, functional cholinergic synapses). The ability to derive BFCN from hESCs is a significant step for the development of therapeutic interventions in diseases affecting the forebrain (e.g. Alzheimer's disease) [103].

BMP9 expression in the CNS seems to be related to the development and maintenance of the cholinergic phenotype. The cited studies give new insights on a clearer comprehension of the role of BMP9 during early embryology and the later ability of damage repair. The proven expression of BMP9 in CNS is also interesting for different reasons: the relation of brain/spinal cord injury and increased ossification potential. As shown in many papers, CNS injury (brain and spinal cord) is associated with an increase in ossification potential (bone healing and HO) [104-109]. However, no specific growth factor has been identified to date [105]. BMP9 would be an interesting candidate to evaluate.

\section{BMP9 AND HEPATOCYTES}

Since BMP9 was first described to be expressed in non parenchymal cells of the liver [20,45], studies have been conducted to determine the effect of BMP9 on liver cells and hepatocellular regeneration [110]. Miller et al. have determined the binding affinity of BMP9 and its number of receptors on rat hepatic endothelial cells (Kd of $\sim 85$ pM, 3600 receptors/cell) and Kupffer cells (Kd of $\sim 25$ pM, 1100 receptors/cell), cells identified as main BMP9 producers. They also found that the binding of BMP9 on these cells was reversible and BMP9/receptor complexes can be internalized [20].

However, while Miller et al. did not detect BMP9 in rat hepatocytes [20], Bidart et al. recently found that BMP9 expression (mRNA and protein) was mainly located in human hepatocytes and biliary hepatic epithelial cells [21]. The effect of BMP9 on hepatocytes was first evaluated by Song et al. [45]. They found that rhBMP9 bind to human HepG2 liver tumor cells with high affinity. They also found that HepG2 cells express two BMP9 receptors similar in size to the Type I and Type II recaptors reported by others for TGF- $\beta$ members, but specific for BMP9 [45]. Increasing doses $(0.1-10 \mathrm{ng} / \mathrm{mL})$ of BMP9 stimulated human HepG2 and primary rat heaptocytes cell proliferation. In contrast, TGF- $\beta$ (0.1 - 100 $\mathrm{ng} / \mathrm{mL}$ ) had no effect on HepG2 cell proliferation but inhibited proliferation in primary hepatocytes [45]. This study was the first to report the effect of BMP9 on heaptocyte proliferation. The direct effect of BMP9 on hepatic progenitor cells was also studied through infections of progenitors with a recombinant adenovirus containing human BMP9 gene (AdBMP9) by Gao et al. (2011). The maturation and differentiation of progenitor cells were examined. AdBMP9 enhanced glycogen storage as well as albumin production in hepatic progenitor cells, a mature hepatic cell behavior [111].

BMP9 is expressed in the liver and seems to have an effect on hepatocytes, but more studies are needed to clarify its differential effect over proliferation [45] and differentiation [111] as well as its neoplastic influence on liver cells [110].

\section{BMP9 AND GLUCOSE METABOLISM}

Insulin resistance is a systemic multifactorial impairment of glucose uptake. Muscle, the most important glucose consuming organ, need Akt2 to be able to activate insulin-induced glucose uptake and this pathway seems to be severely impaired in insulin resistance [112,113]. Interestingly, a combination of bioinformatic and highthroughput functional analyses have shown BMP9 to be the first hepatic factor to regulate blood glucose concentration [46]. Moreover, this effect was thought to be mediated by activation of Akt kinase in differentiated myotubes [46]. Then, it has been demonstrated that recombinant BMP9 (1 and $5 \mathrm{mg} / \mathrm{kg}$ ) improves glucose homeostasis in vivo in diabetic and non-diabetic rodents [46]. The mechanism relied on the upregulation of Smad5 and Akt2 in differentiated rats myotubes [114]. On the opposite side, Smad5 was downregulated in myotubes by dexamethasone, a well known hyperglycemia inducer and Smad5 knockdown in rats decreased Akt2 expression and phosphorylation leading to a decrease in insulin-induced glucose uptake by myotubes. It was then hypothesized that Smad5 regulated glucose uptake in skeletal muscle through Akt2 expression and phosphorylation. These 
findings also revealed Smad5 as a potential target for the treatment of type 2 diabetes. Hence, BMP9 could be seen as a potential activator of Smad5 for that purpose [114].

This promising effect of BMP9 could lead to a better control on hepatic glucose, furthermore on diabetes. Indeed, BMP9 expression is severely reduced in the liver of insulin-resistant rats [115]. In this study, the authors have been reporting several assays showing that BMP9 directly controls glucose homeostasis [115]. Direct in situ exposition of normal fasting rats-liver to glucose and insulin leads to BMP9 expression. Moreover, neutralization of BMP9 with an anti-BMP9 antibody induces glucose intolerance and insulin resistance. Analyzed together, these results reinforce the eligibility of BMP9 as a hepatic insulin-sensitizing substance (HISS) in glucose homeostasis physiology [115].

\section{CONCLUSION}

BMP9 is a powerful osteogenic growth factor and was shown to be able to activate bone differentiation in many animal studies. The osteogenic potential of BMP9 was first studied through gene therapy, but nowadays it is used through its recombinant human form, rhBMP9. The study of BMP9 bone formation has led to a better understanding on endochondral bone healing, but also of the new insights in delivery systems that can enhance its effect as well as improved comprehension of the traumatic $\mathrm{HO}$ and its relation to BMP9. As bone formation is always associated with resorption and remodeling, it has also been shown that BMP9 can directly affect human osteoclasts, acting on their function and their survival. In cancer development, BMP9 has two major effects. First of all, its anti-proliferative/pro-differentiation potential seems to be protective for many neoplastic conditions. On the other hand, its inhibition through ALK1 and endoglin fusion proteins seemed to decrease tumor angiogenesis. Therefore, more studies are warranted in order to clarify its influence on tumorigenesis. On the angiogenic side, we have discussed the sometimes confusing contradictions about the pro and anti-angiogenic effects of BMP9. We have presented the importance of understanding BMP9's role in blood vessel maturation as opposed to formation. The importance of BMP9 in the central nervous system resides in its ability to promote cholinergic neurons proliferation and survival. Looking for new innovative treatment paths in Alzheimer's disease, BMP9 could be an interesting candidate. The relation between liver homeostasis and BMP9 is still not clear, but it is now to our knowledge that it is expressed and produced in that organ. Some studies have tried to show its hepatocellular regeneration potential, but still, more studies are needed. Finally, we have discussed its compelling effect in glucose metabolism, principally promoting sensitivity to insuline in skeletal muscle. Thus,
BMP9 is a major member of the TGF- $\beta$ superfamily that is implied in many fundamental developmental and pathologic processes. Future research will certainly bring answers to the many questions left open, and those answers will unquestionably lead to clinical applications.

\section{ACKNOWLEDGEMENTS}

We are grateful to Dr Juan Sebastian Rendon who did a critical reading of this review anf helped for corrections.

\section{REFERENCES}

[1] Urist, M.R. (1965) Bone: Formation by autoinduction. Science, 150, 893-899.

http://dx.doi.org/10.1126/science.150.3698.893

[2] NCBI. GDF2 growth differentiation 2 [Homo sapiens (human)], Gene, NCBI. http://www.ncbi.nlm.nih.gov/gene/2658

[3] Kishigami, S. and Mishina, Y. (2005) BMP signaling and early embryonic patterning. Cytokine Growth Factor Reviews, 16, 265-278.

[4] Israel, D.I., Nove, J., Kerns, K.M., Kaufman, R.J., Rosen, V., Cox, K.A. and Wozney, J.M. (1996) Heterodimeric bone morphogenetic proteins show enhanced activity in vitro and in vivo. Growth Factors, 13, 291-300. http://dx.doi.org/10.3109/08977199609003229

[5] Aono, A., Hazama, M., Notoya, K., Taketomi, S., Yamasaki, H., Tsukuda, R., Sasaki, S. and Fujisawa, Y. (1995) Potent ectopic bone-inducing activity of bone morphogenetic protein-4/7 heterodimer. Biochemical and Biophysical Research Communications, 210, 670-677. http://dx.doi.org/10.1006/bbrc.1995.1712

[6] Miyazono, K., Maeda, S. and Imamura, T. (2005) BMP receptor signaling: Transcriptional targets, regulation of signals, and signaling cross-talk. Cytokine Growth Factor Reviews, 16, 251-263. http://dx.doi.org/10.1016/j.cytogfr.2005.01.009

[7] Mazerbourg, S. and Hsueh, A.J. (2006) Genomic analyses facilitate identification of receptors and signalling pathways for growth differentiation factor 9 and related orphan bone morphogenetic protein/growth differentiation factor ligands. Human Reproduction Update, 12, 373-383. http://dx.doi.org/10.1093/humupd/dml014

[8] Bessa, P.C., Casal, M. and Reis, R.L. (2008) Bone morphogenetic proteins in tissue engineering: The road from the laboratory to the clinic, part I (basic concepts). Journal of Tissue Engineering and Regenerative Medicine, 2, 1-13. http://dx.doi.org/10.1002/term.63

[9] Wotton, K.R., Alcaine Colet, A., Jaeger, J. and JimenezGuri, E. (2013) Evolution and expression of BMP genes in flies. Development Genes and Evolution, 223, 335-340. http://dx.doi.org/10.1007/s00427-013-0445-9

[10] Kitisin, K., Saha, T., Blake, T., Golestaneh, N., Deng, M., Kim, C., Tang, Y., Shetty, K., Mishra, B. and Mishra, L. (2007) Tgf-Beta signaling in development. Science STKE, 399, cm1. http://dx.doi.org/10.1126/stke.3992007cm1

[11] Chen, D., Zhao, M. and Mundy, G.R. (2004) Bone mor- 
phogenetic proteins. Growth Factors, 22, 233-241. http://dx.doi.org/10.1080/08977190412331279890

[12] Bergeron, E., Senta, H., Mailloux, A., Park, H., Lord, E. and Faucheux, N. (2009) Murine preosteoblast differentiation induced by a peptide derived from bone morphogenetic proteins-9. Tissue Eng Part A, 15, 3341-3349. http://dx.doi.org/10.1089/ten.tea.2009.0189

[13] Kang, Q., Song, W.X., Luo, Q., Tang, N., Luo, J., Luo, X., et al. (2009) A comprehensive analysis of the dual roles of BMPs in regulating adipogenic and osteogenic differentiation of mesenchymal progenitor cells. Stem Cells and Development, 18, 545-559. http://dx.doi.org/10.1089/scd.2008.0130

[14] Kang, Q., Sun, M.H., Cheng, H., Peng, Y., Montag, A.G., Deyrup, A.T., et al., (2004) Characterization of the distinct orthotopic bone-forming activity of 14 BMPs using recombinant adenovirus-mediated gene delivery. Gene Therapy, 11, 1312-1320.

http://dx.doi.org/10.1038/sj.gt.3302298

[15] Cheng, H., Jiang, W., Phillips, F.M., Haydon, R.C., Peng, Y., Zhou, L., et al. (2003) Osteogenic activity of the fourteen types of human bone morphogenetic proteins (BMPs). The Journal of Bone \& Joint Surgery, 85-A, 1544-1552.

[16] Peng, Y., Kang, Q., Cheng, H., Li, X., Sun, M.H., Jiang, W., et al. (2003) Transcriptional characterization of bone morphogenetic proteins (BMPs)-mediated osteogenic signaling. Journal of Cellular Biochemistry, 90, 1149-1165. http://dx.doi.org/10.1002/jcb.10744

[17] Li, J.Z., Hankins, G.R., Kao, C., Li, H., Kammauff, J. and Helm, G.A. (2003) Osteogenesis in rats induced by a novel recombinant helper-dependent bone morphogenetic protein-9 (BMP-9) adenovirus. The Journal of Gene Medicine, 5, 748-756.

http://dx.doi.org/10.1002/jgm.412

[18] Wang, Y., Hong, S., Li, M., Zhang, J., Bi, Y., He, Y., et al. (2013) Noggin resistance contributes to the potent osteogenic capability of BMP9 in mesenchymal stem cells. Journal of Orthopaedic Research. http://dx.doi.org/10.1002/jor.22427

[19] van der Horst, G., van Bezooijen, R.L., Deckers, M.M., Hoogendam, J., Visser, A., Lowik, C.W. and Karperien, M. (2002) Differentiation of murine preosteoblastic KS483 cells depends on autocrine bone morphogenetic protein signaling during all phases of osteoblast formation. Bone, 31, 661-669. http://dx.doi.org/10.1016/S8756-3282(02)00903-1

[20] Miller, A.F., Harvey, S.A., Thies, R.S. and Olson, M.S. (2000) Bone morphogenetic protein-9. An autocrine/paracrine cytokine in the liver. The Journal of Biological Chemistry, 275, 17937-17945. http://dx.doi.org/10.1074/jbc.275.24.17937

[21] Bidart, M., Ricard, N., Levet, S., Samson, M., Mallet, C., David, L., Subileau, M., Tillet, E., Feige, J.J. and Bailly, S. (2012) BMP9 is produced by hepatocytes and circulates mainly in an active mature form complexed to its prodomain. Cellular and Molecular Life Sciences, 69, 313-324. http://dx.doi.org/10.1007/s00018-011-0751-1

[22] David, L., Mallet, C., Keramidas, M., Lamande, N., Gasc,
J.M., Dupuis-Girod, S., Plauchu, H., Feige, J.J. and Bailly, S. (2008) Bone morphogenetic protein-9 is a circulating vascular quiescence factor. Circulation Research, 102, 914-922.

http://dx.doi.org/10.1161/CIRCRESAHA.107.165530

[23] Brown, M.A., Zhao, Q., Baker, K.A., Naik, C., Chen, C., Pukac, L., et al. (2005) Crystal structure of BMP-9 and functional interactions with pro-region and receptors. The Journal of Biological Chemistry, 280, 25111-25118. http://dx.doi.org/10.1074/jbc.M503328200

[24] David, L., Mallet, C., Mazerbourg, S., Feige, J.J. and Bailly, S. (2007) Identification of BMP9 and BMP10 as functional activators of the orphan activin receptor-like kinase 1 (ALK1) in endothelial cells. Blood, 109, 19531961. http://dx.doi.org/10.1182/blood-2006-07-034124

[25] Cunha, S.I. and Pietras, K. (2011) ALK1 as an emerging target for antiangiogenic therapy of cancer. Blood, 117, 6999-7006. http://dx.doi.org/10.1182/blood-2011-01-330142

[26] Attisano, L., Carcamo, J., Ventura, F., Weis, F.M., Massague, J. and Wrana, J.L. (1993) Identification of human activin and TGF beta type I receptors that form heteromeric kinase complexes with type II receptors. Cell, 75, 671-680. http://dx.doi.org/10.1016/0092-8674(93)90488-C

[27] Lamplot, J.D., Qin, J., Nan, G., Wang, J., Liu, X., Yin, L., et al. (2013) BMP9 signaling in stem cell differentiation and osteogenesis. American Journal of Stem Cells, 2, 121.

[28] Bandyopadhyay, A., Yadav, P.S. and Prashar, P. (2013) BMP signaling in development and diseases: A pharmacological perspective. Biochemical Pharmacology, 85, 857-864. http://dx.doi.org/10.1016/j.bcp.2013.01.004

[29] Kim, S.I., Kwak, J.H., Zachariah, M., He, Y., Wang, L. and Choi, M.E. (2007) TGF-beta-activated kinase 1 and TAK1-binding protein 1 cooperate to mediate TGF-beta1-induced MKK3-p38 MAPK activation and stimulation of type I collagen. AJP: Renal Physiology, 292, F1471F1478.

[30] Luo, J., Tang, M., Huang, J., He, B.C., Gao, J.L., Chen, L., et al. (2010) TGF beta\}/BMP type I receptors ALK1 and ALK2 are essential for BMP9-induced osteogenic signaling in mesenchymal stem cells. The Journal of Biological Chemistry.

[31] Townson, S.A., Martinez-Hackert, E., Greppi, C., Lowden, P., Sako, D., Liu, J., et al. (2012) Specificity and structure of a high affinity activin receptor-like kinase 1 (ALK1) signaling complex. The Journal of Biological Chemistry, 287, 27313-27325.

http://dx.doi.org/10.1074/jbc.M112.377960

[32] Luther, G., Wagner, E.R., Zhu, G., Kang, Q., Luo, Q., Lamplot, J., et al. (2011) BMP-9 induced osteogenic differentiation of mesenchymal stem cells: Molecular mechanism and therapeutic potential. Current Gene Therapy, 11, 229-240. http://dx.doi.org/10.2174/156652311795684777

[33] Huang, E., Zhu, G., Jiang, W., Yang, K., Gao, Y., Luo, Q., et al. (2012) Growth hormone synergizes with BMP9 in osteogenic differentiation by activating the JAK/STAT/ 
IGF1 pathway in murine multilineage cells. Journal of Bone and Mineral Research, 27, 1566-1575. http://dx.doi.org/10.1002/jbmr.1622

[34] Liu, X., Qin, J., Luo, Q., Bi, Y., Zhu, G., Jiang, W., et al. (2013) Cross-talk between EGF and BMP9 signalling pathways regulates the osteogenic differentiation of mesenchymal stem cells. Journal of Cellular and Molecular Medicine. http://dx.doi.org/10.1111/jcmm.12097

[35] Suttapreyasri, S., Koontongkaew, S., Phongdara, A. and Leggat, U. (2006) Expression of bone morphogenetic proteins in normal human intramembranous and endochondral bones. International Journal of Oral and Maxillofacial Surgery, 35, 444-452.

http://dx.doi.org/10.1016/j.ijom.2006.01.021

[36] Celeste, A.J., Song, J.J., Cox, K.A., Rosen, V. and Wozney, J.M. (1994) Bone morphogenetic protein-9, a new member of the TGF beta superfamily. Journal of Bone and Mineral Research, 9, 136.

[37] Alden, T.D., Beres, E.J., Laurent, J.S., Engh, J.A., Das, S., London, S.D., Jane Jr., J.A., Hudson, S.B. and Helm, G.A. (2000) The use of bone morphogenetic protein gene therapy in craniofacial bone repair. Journal of Craniofacial Surgery, 11, 24-30. http://dx.doi.org/10.1097/00001665-200011010-00005

[38] Epstein, N.E. (2011) Pros, cons, and costs of INFUSE in spinal surgery. Surgical Neurology International, 2, 10. http://dx.doi.org/10.4103/2152-7806.76147

[39] Helm, G.A., Alden, T.D., Beres, E.J., Hudson, S.B., Das, S., Engh, J.A., Pittman, D.D., Kerns, K.M. and Kallmes, D.F. (2000) Use of bone morphogenetic protein-9 gene therapy to induce spinal arthrodesis in the rodent. Journal of Neurosurgery, 92, 191-196. http://dx.doi.org/10.3171/spi.2000.92.2.0191

[40] Dumont, R.J., Dayoub, H., Li, J.Z., Dumont, A.S., Kallmes, D.F., Hankins, G.R. and Helm, G.A. (2002) Ex vivo bone morphogenetic protein-9 gene therapy using human mesenchymal stem cells induces spinal fusion in rodents. Neurosurgery, 51, 1239-1244.

[41] Dayoub, H., Dumont, R.J., Li, J.Z., Dumont, A.S., Hankins, G.R., Kallmes, D.F. and Helm, G.A. (2003) Human mesenchymal stem cells transduced with recombinant bone morphogenetic protein-9 adenovirus promote osteogenesis in rodents. Tissue Engineering, 9, 347-356. http://dx.doi.org/10.1089/107632703764664819

[42] Abdelaal, M.M., Tholpady, S.S., Kessler, J.D., Morgan, R.F. and Ogle, R.C. (2004) BMP-9-transduced prefabricated muscular flaps for the treatment of bony defects. Journal of Craniofacial Surgery, 15, 736-741. http://dx.doi.org/10.1097/00001665-200409000-00007

[43] Aslan, H., Zilberman, Y., Arbeli, V., Sheyn, D., Matan, Y., Liebergall, M., Li, J.Z., Helm, G.A., Gazit, D. and Gazit, Z. (2006) Nucleofection-based ex vivo nonviral gene delivery to human stem cells as a platform for tissue regeneration. Tissue Engineering, 12, 877-889. http://dx.doi.org/10.1089/ten.2006.12.877

[44] Itakura, K., Hirose, T., Crea, R., Riggs, A.D., Heyneker, H.L., Bolivar, F. and Boyer, H.W. (1977) Expression in Escherichia coli of a chemically synthesized gene for the hormone somatostatin. Science, 198, 1056-1063.

\section{http://dx.doi.org/10.1126/science.412251}

[45] Song, J.J., Celeste, A.J., Kong, F.M., Jirtle, R.L., Rosen, V. and Thies, R.S. (1995) Bone morphogenetic protein-9 binds to liver cells and stimulates proliferation. Endocrinology, 136, 4293-4297. http://dx.doi.org/10.1210/en.136.10.4293

[46] Chen, C., Grzegorzewski, K.J., Barash, S., Zhao, Q., Schneider, H., Wang, Q., et al. (2003) An integrated functional genomics screening program reveals a role for BMP-9 in glucose homeostasis. Nature Biotechnology, 21, 294-301.

[47] Bessa, P.C., Cerqueira, M.T., Rada, T., Gomes, M.E., Neves, N.M., Nobre, A., Reis, R.L. and Casal, M. (2009) Expression, purification and osteogenic bioactivity of recombinant human BMP-4, -9, -10, -11 and -14. Protein Expression and Purification, 63, 89-94. http://dx.doi.org/10.1016/j.pep.2008.09.014

[48] Bergeron, E., Marquis, M.E., Chretien, I. and Faucheux, N. (2007) Differentiation of preosteoblasts using a delivery system with BMPs and bioactive glass microspheres. Journal of Materials Science: Materials in Medicine, 18, 255-263. http://dx.doi.org/10.1007/s10856-006-0687-4

[49] Wozney, J.M., Rosen, V., Celeste, A.J., Mitsock, L.M., Whitters, M.J., Kriz, R.W., Hewick, R.M. and Wang, E.A. (1988) Novel regulators of bone formation: Molecular clones and activities. Science, 242, 1528-1534. http://dx.doi.org/10.1126/science.3201241

[50] Glaser, D.L., Economides, A.N., Wang, L., Liu, X., Kimble, R.D., Fandl, J.P., Wilson, J.M., Stahl, N., Kaplan, F.S. and Shore, E.M. (2003) In vivo somatic cell gene transfer of an engineered Noggin mutein prevents BMP4induced heterotopic ossification. The Journal of Bone \& Joint Surgery, 85-A, 2332-2342.

[51] Clever, J.L., Sakai, Y., Wang, R.A. and Schneider, D.B. (2010) Inefficient skeletal muscle repair in inhibitor of differentiation knockout mice suggests a crucial role for BMP signaling during adult muscle regeneration. American Journal of Physiology, 298, C1087-C1099. http://dx.doi.org/10.1152/ajpcell.00388.2009

[52] Ono, Y., Calhabeu, F., Morgan, J.E., Katagiri, T., Amthor, H. and Zammit, P.S. (2010) BMP signalling permits population expansion by preventing premature myogenic differentiation in muscle satellite cells. Cell Death and Differentiation, 18, 222-234. http://dx.doi.org/10.1038/cdd.2010.95

[53] Katagiri, T., Yamaguchi, A., Komaki, M., Abe, E., Takahashi, N., Ikeda, T., Rosen, V., Wozney, J.M., Fujisawa-Sehara, A. and Suda, T. (1994) Bone morphogenetic protein-2 converts the differentiation pathway of C2C12 myoblasts into the osteoblast lineage. The Journal of Cell Biology, 127, 1755-1766. http://dx.doi.org/10.1083/jcb.127.6.1755

[54] Oishi, T., Uezumi, A., Kanaji, A., Yamamoto, N., Yamaguchi, A., Yamada, H. and Tsuchida, K. (2013) Osteogenic differentiation capacity of human skeletal musclederived progenitor cells. PLoS One, 8, e56641. http://dx.doi.org/10.1371/journal.pone.0056641

[55] Jackson, W.M., Aragon, A.B., Bulken-Hoover, J.D., 
Nesti, L.J. and Tuan, R.S. (2009) Putative heterotopic ossification progenitor cells derived from traumatized muscle. Journal of Orthopaedic Research, 27, 1645-1651. http://dx.doi.org/10.1002/jor.20924

[56] Leblanc, E., Trensz, F., Haroun, S., Drouin, G., Bergeron, E., Penton, C.M., Montanaro, F., Roux, S., Faucheux, N. and Grenier, G. (2011) BMP9-Induced muscle heterotopic ossification requires changes to the skeletal muscle microenvironment. Journal of Bone and Mineral Research, 26, 1166-1177. http://dx.doi.org/10.1002/jbmr.311

[57] Lauzon, M.A., Bergeron, E., Marcos, B. and Faucheux, N. (2012) Bone repair: New developments in growth factor delivery systems and their mathematical modeling. Journal of Controlled Release, 162, 502-520. http://dx.doi.org/10.1016/j.jconrel.2012.07.041

[58] Bergeron, E., Leblanc, E., Drevelle, O., Giguere, R., Beauvais, S., Grenier, G. and Faucheux, N. (2012) The evaluation of ectopic bone formation induced by delivery systems for bone morphogenetic protein-9 or its derived peptide. Tissue Engineering Part A, 18, 342-352. http://dx.doi.org/10.1089/ten.tea.2011.0008

[59] Bessa, P.C., Balmayor, E.R., Azevedo, H.S., Nurnberger, S., Casal, M., van Griensven, M., Reis, R.L. and Redl, H. (2010) Silk fibroin microparticles as carriers for delivery of human recombinant BMPs. Physical characterization and drug release. Journal of Tissue Engineering and Regenerative Medicine, 4, 349-355.

[60] Drevelle, O., Daviau, A., Lauzon, M.A. and Faucheux, N. (2013) Effect of BMP-2 and/or BMP-9 on preosteoblasts attached to polycaprolactone functionalized by adhesive peptides derived from bone sialoprotein. Biomaterials, 34, 1051-1062. http://dx.doi.org/10.1016/j.biomaterials.2012.10.066

[61] Marquis, M.E., Lord, E., Bergeron, E., Bourgoin, L. and Faucheux, N. (2008) Short-term effects of adhesion peptides on the responses of preosteoblasts to pBMP-9. Biomaterials, 29, 1005-1016. http://dx.doi.org/10.1016/j.biomaterials.2007.10.047

[62] Miller, M.D. (2008) Review of orthopaedics. Saunders/ Elsevier, Philadelphia.

[63] Goldring, M.B., Tsuchimochi, K. and Ijiri, K. (2005) The control of chondrogenesis. Journal of Cellular Biochemistry, 97, 33-44. http://dx.doi.org/10.1002/jcb.20652

[64] Hidaka, C. and Goldring, M.B. (2008) Regulatory mechanisms of chondrogenesis and implications for understanding articular cartilage homeostasis. Current Rheumatology Reviews, 4, 136-147.

http://dx.doi.org/10.2174/157339708785133541

[65] Pizette, S. and Niswander, L. (2000) BMPs are required at two steps of limb chondrogenesis: Formation of prechondrogenic condensations and their differentiation into chondrocytes. Developmental Biology, 219, 237-249. http://dx.doi.org/10.1006/dbio.2000.9610

[66] Yoon, B.S., Ovchinnikov, D.A., Yoshii, I., Mishina, Y., Behringer, R.R. and Lyons, K.M. (2005) Bmpr1a and Bmpr1b have overlapping functions and are essential for chondrogenesis in vivo. Proceedings of the National Aca- demy of Sciences of the United States of America, 102, 5062-5067.

[67] Kramer, J., Hegert, C., Guan, K., Wobus, A.M., Muller, P.K. and Rohwedel, J. (2000) Embryonic stem cell-derived chondrogenic differentiation in vitro: Activation by BMP-2 and BMP-4. Mechanisms of Development, 92, 193-205. http://dx.doi.org/10.1016/S0925-4773(99)00339-1

[68] Chubinskaya, S. and Kuettner, K.E. (2003) Regulation of osteogenic proteins by chondrocytes. The International Journal of Biochemistry \& Cell Biology, 35, 1323-1340. http://dx.doi.org/10.1016/S1357-2725(03)00035-9

[69] Yeh, L.C., Mallein-Gerin, F. and Lee, J.C. (2002) Differential effects of osteogenic protein-1 (BMP-7) on gene expression of BMP and GDF family members during differentiation of the mouse MC615 chondrocyte cells. Journal of Cellular Physiology, 191, 298-309. http://dx.doi.org/10.1002/jcp.10094

[70] Chubinskaya, S., Merrihew, C., Cs-Szabo, G., Mollenhauer, J., McCartney, J., Rueger, D.C. and Kuettner, K.E. (2000) Human articular chondrocytes express osteogenic protein-1. Journal of Histochemistry \& Cytochemistry, 48, 239-250.

[71] Varady, P., Li, J.Z., Cunningham, M., Beres, E.J., Das, S., Engh, J., Alden, T.D., Pittman, D.D., Kerns, K.M., Kallmes, D.F. and Helm, G.A. (2001) Morphologic analysis of BMP-9 gene therapy-induced osteogenesis. Human Gene Therapy, 12, 697-710. http://dx.doi.org/10.1089/104303401300057423

[72] Majumdar, M.K., Wang, E. and Morris, E.A. (2001) BMP-2 and BMP-9 promotes chondrogenic differentiation of human multipotential mesenchymal cells and overcomes the inhibitory effect of IL-1. Journal of Cellular Physiology, 189, 275-284. http://dx.doi.org/10.1002/jcp.10025

[73] Blunk, T., Sieminski, A.L., Appel, B., Croft, C., Courter, D.L., Chieh, J.J., Goepferich, A., Khurana, J.S. and Gooch, K.J. (2003) Bone morphogenetic protein 9: A potent modulator of cartilage development in vitro. Growth Factors, 21, 71-77. http://dx.doi.org/10.1080/0897719031000148822

[74] Fong, D., Bisson, M., Laberge, G., McManus, S., Grenier, G., Faucheux, N. and Roux, S. (2013) Bone morphogenetic protein-9 activates smad and ERK pathways and supports human osteoclast function and survival in vitro. Cellular Signalling, 25, 717-728.

http://dx.doi.org/10.1016/j.cellsig.2012.12.003

[75] Castonguay, R., Werner, E.D., Matthews, R.G., Presman, E., Mulivor, A.W., Solban, N., et al. (2011) Soluble endoglin specifically binds bone morphogenetic proteins 9 and 10 via its orphan domain, inhibits blood vessel formation, and suppresses tumor growth. The Journal of Biological Chemistry, 286, 30034-30046.

http://dx.doi.org/10.1074/jbc.M111.260133

[76] Ye, L., Kynaston, H. and Jiang, W.G. (2008) Bone morphogenetic protein-9 induces apoptosis in prostate cancer cells, the role of prostate apoptosis response-4. Molecular Cancer Research, 6, 1594-1606.

http://dx.doi.org/10.1158/1541-7786.MCR-08-0171 
[77] Li, B., Yang, Y., Jiang, S., Ni, B., Chen, K. and Jiang, L. (2012) Adenovirus-mediated overexpression of BMP-9 inhibits human osteosarcoma cell growth and migration through downregulation of the PI3K/AKT pathway. International Journal of Oncology, 41, 1809-1819.

[78] Cunha, S.I., Pardali, E., Thorikay, M., Anderberg, C., Hawinkels, L., Goumans, M.J., Seehra, J., Heldin, C.H., ten Dijke, P. and Pietras, K. (2010) Genetic and pharmacological targeting of activin receptor-like kinase 1 impairs tumor growth and angiogenesis. The Journal of Experimental Medicine, 207, 85-100.

[79] Suzuki, Y., Ohga, N., Morishita, Y., Hida, K., Miyazono, K. and Watabe, T. (2010) BMP-9 induces proliferation of multiple types of endothelial cells in vitro and in vivo. Journal of Cell Science, 123, 1684-1692.

[80] Luo, X., Chen, J., Song, W.X., Tang, N., Luo, J., Deng, Z.L., et al. (2008) Osteogenic BMPs promote tumor growth of human osteosarcomas that harbor differentiation defects. Laboratory Investigation, 88, 1264-1277. http://dx.doi.org/10.1038/labinvest.2008.98

[81] Park, H., Drevelle, O., Daviau, A., Senta, H., Bergeron, E. and Faucheux, N. (2012) Preventing MEK1 activation influences the responses of human osteosarcoma cells to bone morphogenetic proteins 2 and 9. Anticancer Drugs, 24, 278-290. http://dx.doi.org/10.1097/CAD.0b013e32835cbde7

[82] Lv, Z., Yang, D., Li, J., Hu, M., Luo, M., Zhan, X., Song, P., Liu, C., Bai, H., Li, B., Yang, Y., Chen, Y., Shi, Q. and Weng, Y. (2013) Bone morphogenetic protein 9 overexpression reduces osteosarcoma cell migration and invasion. Molecules and Cells, 36, 119-126. http://dx.doi.org/10.1007/s10059-013-0043-8

[83] Spanjol, J., Djordjevic, G., Markic, D., Klaric, M., Fuckar, D. and Bobinac, D. (2010) Role of bone morphogenetic proteins in human prostate cancer pathogenesis and development of bone metastases: Immunohistochemical study. Collegium Antropologicum, 34, 119-125.

[84] David, L., Feige, J.J. and Bailly, S. (2009) Emerging role of bone morphogenetic proteins in angiogenesis. Cytokine \& Growth Factor Reviews, 20, 203-212. http://dx.doi.org/10.1016/j.cytogfr.2009.05.001

[85] Mitchell, D., Pobre, E.G., Mulivor, A.W., Grinberg, A.V., Castonguay, R., Monnell, T.E., Solban, N., Ucran, J.A., Pearsall, R.S., Underwood, K.W., Seehra, J. and Kumar, R. (2010) ALK1-Fc inhibits multiple mediators of angiogenesis and suppresses tumor growth. Molecular Cancer Therapy, 9, 379-388. http://dx.doi.org/10.1158/1535-7163.MCT-09-0650

[86] Ricard, N., Bidart, M., Mallet, C., Lesca, G., Giraud, S., Prudent, R., Feige, J.J. and Bailly, S. (2010) Functional analysis of the BMP9 response of ALK1 mutants from HHT2 patients: A diagnostic tool for novel ACVRL1 mutations. Blood, 116, 1604-1612.

[87] Herrera, B. and Inman, G.J. (2009) A rapid and sensitive bioassay for the simultaneous measurement of multiple bone morphogenetic proteins. Identification and quantification of BMP4, BMP6 and BMP9 in bovine and human serum. BMC Cell Biology, 10, 20. http://dx.doi.org/10.1186/1471-2121-10-20
[88] Haitjema, T., Westermann, C.J., Overtoom, T.T., Timmer, R., Disch, F., Mauser, H. and Lammers, J.W. (1996) Hereditary hemorrhagic telangiectasia (Osler-Weber-Rendu disease): New insights in pathogenesis, complications, and treatment. Archives of Internal Medicine, 156, 714719.

http://dx.doi.org/10.1001/archinte.1996.00440070028004

[89] Mahmoud, M., Upton, P.D. and Arthur, H.M. (2011) Angiogenesis regulation by TGFbeta signalling: Clues from an inherited vascular disease. Biochemical Society Transactions, 39, 1659-1666. http://dx.doi.org/10.1042/BST20110664

[90] Alt, A., Miguel-Romero, L., Donderis, J., Aristorena, M., Blanco, F.J., Round, A., Rubio, V., Bernabeu, C. and Marina, A. (2012) Structural and functional insights into endoglin ligand recognition and binding. PLoS One, 7, e29948. http://dx.doi.org/10.1371/journal.pone.0029948

[91] Bailly, S., Dupuis-Girod, S. and Plauchu, H. (2010) Rendu-osler disease: Clinical and molecular update. Medicine/Science (Paris), 26, 855-860.

http://dx.doi.org/10.1051/medsci/20102610855

[92] Choi, E.J., Kim, Y.H., Choe, S.W., Tak, Y.G., GarridoMartin, E.M., Chang, M., Lee, Y.J. and Oh, S.P. (2013) Enhanced responses to angiogenic cues underlie the pathogenesis of hereditary hemorrhagic telangiectasia 2 . PLoS One, 8, e63138. http://dx.doi.org/10.1371/journal.pone.0063138

[93] Somekawa, S., Imagawa, K., Hayashi, H., Sakabe, M., Ioka, T., Sato, G.E., Inada, K., Iwamoto, T., Mori, T., Uemura, S., Nakagawa, O. and Saito, Y. (2012) Tmem100, an ALK1 receptor signaling-dependent gene essential for arterial endothelium differentiation and vascular morphogenesis. Proceedings of the National Academy of Sciences of the United States of America, 109, 12064-12069.

[94] Chida, A., Shintani, M., Yagi, H., Fujiwara, M., Kojima, Y., Sato, H., et al. (2013) Outcomes of childhood pulmonary arterial hypertension in BMPR2 and ALK1 mutation carriers. American Journal of Cardiology, 110, 586-593.

[95] Dunmore, B.J., Drake, K.M., Upton, P.D., Toshner, M.R., Aldred, M.A. and Morrell, N.W. (2013) The lysosomal inhibitor, chloroquine, increases cell surface BMPR-II levels and restores BMP9 signalling in endothelial cells harbouring BMPR-II mutations. Human Molecular Genetics, 22, 3667-3679

[96] Bachiller, D., Klingensmith, J., Kemp, C., Belo, J.A., Anderson, R.M., May, S.R., McMahon, J.A., McMahon, A.P., Harland, R.M., Rossant, J. and De Robertis, E.M. (2000) The organizer factors chordin and noggin are required for mouse forebrain development. Nature, 403, 658-661.

[97] Weinstein, D.C. and Hemmati-Brivanlou, A. (1999) Neural induction. Annual Review of Cell and Developmental Biology, 15, 411-433. http://dx.doi.org/10.1146/annurev.cellbio.15.1.411

[98] Lopez-Coviella, I., Mellott, T.M., Kovacheva, V.P., Berse, B., Slack, B.E., Zemelko, V., Schnitzler, A. and Blusztajn, J.K. (2006) Developmental pattern of expression of BMP receptors and smads and activation of 
Smad1 and Smad5 by BMP9 in mouse basal forebrain. Brain Research, 1088, 49-56. http://dx.doi.org/10.1016/j.brainres.2006.02.073

[99] Lopez-Coviella, I., Berse, B., Krauss, R., Thies, R.S. and Blusztajn, J.K. (2000) Induction and maintenance of the neuronal cholinergic phenotype in the central nervous system by BMP-9. Science, 289, 313-316. http://dx.doi.org/10.1016/j.brainres.2006.02.073

[100] Wu, C.K., Thal, L., Pizzo, D., Hansen, L., Masliah, E. and Geula, C. (2005) Apoptotic signals within the basal forebrain cholinergic neurons in Alzheimer's disease. Experimental Neurology, 195, 484-496. http://dx.doi.org/10.1016/j.expneurol.2005.06.020

[101] Lopez-Coviella, I., Follettie, M.T., Mellott, T.J., Kovacheva, V.P., Slack, B.E., Diesl, V., Berse, B., Thies, R.S. and Blusztajn, J.K. (2005) Bone morphogenetic protein 9 induces the transcriptome of basal forebrain cholinergic neurons. Proceedings of the National Academy of Sciences of the United States of America, 102, 6984-6989.

[102] Lopez-Coviella, I., Mellott, T.J., Schnitzler, A.C. and Blusztajn, J.K. (2011) BMP9 protects septal neurons from axotomy-evoked loss of cholinergic phenotype. PLoS One, 6, e21166. http://dx.doi.org/10.1371/journal.pone.0021166

[103] Bissonnette, C.J., Lyass, L., Bhattacharyya, B.J., Belmadani, A., Miller, R.J. and Kessler, J.A. (2011) The controlled generation of functional basal forebrain cholinergic neurons from human embryonic stem cells. Stem Cells, 29, 802-811.

http://dx.doi.org/10.1002/stem.626

[104] Citta-Pietrolungo, T.J., Alexander, M.A. and Steg, N.L. (1992) Early detection of heterotopic ossification in young patients with traumatic brain injury. Archives of Physical Medicine and Rehabilitation, 73, 258-262.

[105] Gautschi, O.P., Cadosch, D., Frey, S.P., Skirving, A.P., Filgueira, L. and Zellweger, R. (2009) Serum-mediated osteogenic effect in traumatic brain-injured patients. ANZ Journal of Surgery, 79, 449-455. http://dx.doi.org/10.1111/j.1445-2197.2008.04803.x

[106] Cadosch, D., Gautschi, O.P., Thyer, M., Song, S., Skirving, A.P., Filgueira, L. and Zellweger, R. (2009) Humoral factors enhance fracture-healing and callus formation in patients with traumatic brain injury. The Journal of Bone \& Joint Surgery, 91, 282-288. http://dx.doi.org/10.2106/JBJS.G.01613

[107] Cipriano, C.A., Pill, S.G. and Keenan, M.A. (2009) He- terotopic ossification following traumatic brain injury and spinal cord injury. Journal of the American Academy of Orthopaedic Surgeons, 17, 689-697.

[108] Gautschi, O.P., Toffoli, A.M., Joesbury, K.A., Skirving, A.P., Filgueira, L. and Zellweger, R. (2007) Osteoinductive effect of cerebrospinal fluid from brain-injured patients. Journal of Neurotrauma, 24, 154-162. http://dx.doi.org/10.1089/neu.2006.0166

[109] Toffoli, A.M., Gautschi, O.P., Frey, S.P., Filgueira, L. and Zellweger, R. (2008) From brain to bone: Evidence for the release of osteogenic humoral factors after traumatic brain injury. Brain Injury, 22, 511-518. http://dx.doi.org/10.1080/02699050802158235

[110] Sosa, I., Cvijanovic, O., Celic, T., Cuculic, D., CrncevicOrlic, Z., Vukelic, L., Zoricic-Cvek, S., Dudaric, L., Bosnar, A. and Bobinac, D. (2011) Hepatoregenerative role of bone morphogenetic protein-9. Medical Science Monitor, 17, 33-35. http://dx.doi.org/10.12659/MSM.882108

[111] Gao, Y.L., Cai, X.F., Liu, J., Shan, X.L., Chen, Q.M., Zhou, F. and Tang, N. (2011) Hepatic lineage differentiation of hepatic progenitor cells by bone morphogenetic protein or leukemia inhibitory factor. Zhonghua Gan Zang Bing Za Zhi, 19, 692-695.

[112] George, S., Rochford, J.J., Wolfrum, C., Gray, S.L., Schinner, S., Wilson, J.C., et al. (2004) A family with severe insulin resistance and diabetes due to a mutation in AKT2. Science, 304, 1325-1328.

[113] Cho, H., Mu, J., Kim, J.K., Thorvaldsen, J.L., Chu, Q., Crenshaw, E.B., 3rd, Kaestner, K.H., Bartolomei, M.S., Shulman, G.I. and Birnbaum, M.J. (2001) Insulin resistance and a diabetes mellitus-like syndrome in mice lacking the protein kinase Akt2 (PKB beta). Science, 292, 1728-1731.

[114] Anhe, F.F., Lellis-Santos, C., Leite, A.R., Hirabara, S.M., Boschero, A.C., Curi, R., Anhe, G.F. and Bordin, S. (2010) Smad5 regulates Akt2 expression and insulin-induced glucose uptake in L6 myotubes. Molecular and Cellular Endocrinology, 319, 30-38. http://dx.doi.org/10.1126/science.292.5522.1728

[115] Caperuto, L.C., Anhe, G.F., Cambiaghi, T.D., Akamine, E.H., do Carmo Buonfiglio, D., Cipolla-Neto, J., Curi, R. and Bordin, S. (2008) Modulation of bone morphogenetic protein-9 expression and processing by insulin, glucose, and glucocorticoids: Possible candidate for hepatic insulin-sensitizing substance. Endocrinology, 149, 63266335. 